\title{
Demand for Environmental Quality: An Empirical Analysis of Consumer Behavior in Sweden ${ }^{\dagger}$
}

\author{
Tarek Ghalwash \\ Department of Economics, Umeå University \\ SE-901 87 Umeå, Sweden
}

\begin{abstract}
In this paper we estimate the income elasticity of demand for recreational services and other traditional groups of goods in Sweden and test for potential changes in such estimates over the twentieth century. Due to the difficulty of directly observing the demand for recreational services, we employ an indirect methodology by using the demand for some outdoor goods as a proxy for the demand for recreational services. In line with most prior research, our results confirm the expectation that recreational services, as a public good, is a luxury good in Sweden. Our results also show that the income elasticities for traditional goods are stable over time, indicating that consumer preferences for expenditure on these specific commodities do not change over time.
\end{abstract}

Keywords: Household demand; environmental services; income elasticities; Engel curves.

JEL Classification: D12; H41; Q26.

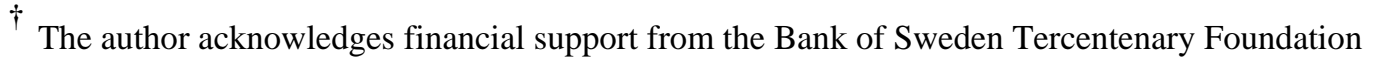
(Riksbankens Jubileumsfond, Kulturdonationen). The author also wishes to thank Runar Brännlund, Jonas Nordström, Peter Berck, and Karl-Gustaf Löfgren for valuable comments.
} 
Demand for Environmental Quality 


\section{Introduction}

One of the main goals in studying individual consumption behavior is to analyze the relationships between commodity expenditure and income or total expenditure (i.e. the well-known Engel curves). There are several reasons why these relationships are of interest. Firstly, it may be useful to see how demand for various goods develops under different growth scenarios. A second reason is to determine whether consumer preferences regarding various commodities have changed over time.

The main objective of this paper is to compare how demand for recreational services and other major private goods in Sweden reacts to changes in income and, in particular, how these reactions have changed over time. Specifically, we investigate how the income elasticity in Sweden has changed over time with respect to some specific goods that are closely related (complementary) to environmental services. ${ }^{1}$ Because consumption of recreational services is not directly observed in the market, the study uses the demand for complementary market products as a proxy for the demand for environmental services. Further, the objective of this paper is closely related to the notion of an environmental Kuznets curve (EKC), which describes a specific relation between environmental quality and growth.

Several studies have examined the income elasticity for different commodities using data from different countries in different time frames. For example, Segal (2001) reports that the budget share for food has fallen dramatically in the United States over the twentieth century, from 50\% for poor households and 30\% for affluent households in 1901 to $10-15 \%$ in 1999. Segal's (2001) finding reaffirms Engel's law of food from 1895. ${ }^{2}$ On the other hand, Segal (2001) found that the budget share for transportation increased from about $2 \%$ to more than $20 \%$. Such results indicate a remarkable instability of the budget share for food and transportation expenditure in the U.S. over the century.

For convenience, we use the label "environmental services" for all goods and services provided by the environmental and the ecological system, including environmental quality, see for example, Mäler (1974).

2 Formulated by German-born statistician, Ernst Engel (1821-1896), Engel's Law states that as incomes increase, the proportion of income spent on food falls. 
Larsen (2001) used Norwegian survey data on purchasing behavior for equipment and lodging over the period 1986-1995. He found that the income elasticity was fairly stable over time, and that both equipment and lodging were luxury goods over the whole period. Further, Miles et al. (2002) used several models, both parametric and nonparametric, to estimate Engel curves using survey data from Uruguay. They found that the results differ substantially depending on model specification and estimation method. However, their results support the hypothesis that the environment is a luxury good in Uruguay. Kriström and Riera (1996) using estimates of the willingness to pay for environmental goods for different European countries (Finland, France, Norway, Holland, Spain and Sweden), found that the hypothesis that environmental goods are necessary goods cannot be rejected in most cases (income elasticity is less than one).

The estimation of income elasticities over several years has strict requirements for data. The data sets must be comparable, span a substantial period, be of high quality, exhaustively cover expenditure opportunities, and preferably be random samples. The Swedish Family Expenditure Survey (FES) have some attractive features for the question at hand: respondents are randomly selected, data contain information of actual market behavior where budget constraints are observed and obeyed, the classifications of goods are retained over time and the choice set is saturated and exhausts purchase possibilities. Time trends are detectable since data span a considerable time period and are comparable over time. This paper uses FES data for 1913, 1984, 1988, and 1996.

The rest of the paper is organized as follows: In the next two sections, we elaborate further on the existing literature, as well as on the theoretical framework for our empirical investigation. Our econometric model is presented in section 4. Section 5 describes the data used in the study. The results from the model are presented in section 6. Finally, a short summary and some concluding remarks are given in section 7 .

\section{Previous Studies}

Much discussion exists in the economic literature of the possible effects of income and economic growth on the environment, including speculation on the possible existence of an “environmental Kuznets curve”. This curve shows an inverted U-shaped relation between pollution and per capita income, indicating that in the early stages of a country's economic development pollution increases up to a turning point and then 
begins to decrease as per capita income increases further. The EKC idea has triggered a good deal of research, theoretical as well as empirical. The theoretical literature has focused mostly on assumptions regarding the relationship between technology/preferences and emissions (Lopez, 1994, Selden and Song, 1995, McConell, 1997, Chichilnisky 1998, de Groot 1999). In general, empirical models are of a reduced form type using cross country data (Grossman and Krueger, 1995, Stern and Common, 2001). An obvious drawback with most of the empirical models is that they can only describe the relation, not explain it. To understand the mechanisms at work, we need further knowledge about technological progress and how consumer preferences are formed.

Clearly related to this issue is the question of how consumer demand for recreational services and environmental goods reacts to income changes. If the income elasticity is greater than one, this would be consistent with the EKC hypothesis. However, income elasticity is also important from a distributional perspective, since it will tell us which groups in society will reap the benefits of projects that improve environmental services. Therefore, such estimates of demand and income elasticity of recreational services and environmental goods may provide significant information to any cost-benefit analysis or ex-post project evaluation; see Kanninen and Kriström (1992), Kriström and Riera (1996), and Hökby and Söderqvist (2001).

The basic problem in the estimation of income elasticity for environmental goods is that we cannot directly observe individual demand for recreational services due to its public good and/or non-market priced nature. Therefore, we cannot directly estimate the income elasticity for such goods. To overcome this problem, two different approaches are suggested in the literature. The first approach is to use "stated preference" data, ${ }^{3}$ and the second is to employ an indirect estimation technique derived from the fact that households have to purchase complementary goods.

The first approach is a direct approach based on contingent valuation surveys (Kriström and Riera, 1996, Hökby and Söderqvist, 2001). Under this approach, willingness to pay data is regressed on income and other individual characteristics. In Kriström and Riera

3 This approach mainly relies on individuals' hypothetical behavior on markets set up for environmental service in some survey setting. The contingent valuation method (CVM) is widely used in this approach (Mitchell and Carson, 1989 and Batemen and Willis, 1999). 
(1996) willingness to pay data for various environmental goods in a number of European countries are regressed on income. Contrary to the conventional wisdom, Kriström and Riera found that willingness to pay for environmental improvements decreases with income, which indicates that the income elasticity is lower than one. Using the same methodology, Hökby and Söderqvist (2001) found similar results. A problem with this approach is that the magnitude of the willingness to pay elasticity with respect to income may not give complete information concerning the demand elasticity with respect to income. ${ }^{4}$ To address this problem, Hökby and Söderqvist also merge data from several willingness to pay studies for the same environmental good, reduced marine eutrophication in the Baltic Sea, and again found that the income elasticity for reduced eutrophication is less than one.

The second approach is an indirect estimation approach based on the fact that individuals, in order to generate utility from the environment, need private goods that are bought and sold in the market and, therefore, can be observed. For example, to enjoy the excitement of a salmon river it is necessary to have some fishing gear, or at least some outdoor gear. Thus, if demand for fishing gear and other goods that are closely related to the "consumption" of environmental amenities increase more than proportionally with the increase in income, the interpretation may be that the environment is a luxury good (Mäler, 1974).

There are a number of previous studies that have used the indirect approach, such as Costa (1997), Pereyra and Rossi (1998), Miles et al. (2002), and Larsen (2001). Costa (1997), using U.S. data, reported elasticities greater than one for recreation goods. However, she found that these elasticities decreased significantly over the last hundred years. Pereyra and Rossi (1998) applied a parametric method using data from Uruguay and found corroborative evidence that environmental goods constitute a luxury good. Miles et al. (2002) used parametric estimates to confirm the hypothesis that the outdoor recreational services constitute a luxury good in Uruguay. Larsen (2001) used Norwegian survey data on purchasing behavior for equipment and lodging over the period 1986-1995 to estimate Engel curves. He found that the income elasticity was

\footnotetext{
4 The income elasticity of willingness to pay and the ordinary income elasticity of demand are related. However, knowledge of one is insufficient to determine the magnitude or even the sign of the other. The income elasticity of willingness to pay is influenced by additional factors that are generally unobservable. For more details, see Flores and Carson (1997).
} 
fairly stable over time, and that both equipment and lodging were luxury goods over the whole period.

In this study, we follow the second approach, using household survey data for Sweden. Using this data, we estimate Engel curves for private goods that are used in the production of environmental services. As well as estimating the income elasticity for proxy goods used for recreational services (outdoor recreation), we also estimate the income elasticity of demand for other traditional market goods in Sweden over the same period in order to compare relative changes in consumer preferences.

To achieve our objectives, we formulate and estimate an econometric model for purely private goods and for private goods that are complementary to public goods. The model employed is based on the assumption of a two-stage budgeting process. It is assumed that in the first stage, the household allocates its total expenditure for purely private goods and goods complementary to recreation on different commodity aggregates, or groups. There are five groups: one group of goods complementary to outdoor recreation, and four purely private groups: food, transportation, energy goods, and other goods. Given the allocation to each commodity group, households in the second stage allocate their group expenditures on the various goods within the group. Our econometric model is based on Deaton \& Muellbauer's (1980) almost ideal model (AIDS). The inclusion of data from a budget survey for 1913 enables us to compare the results over a longer time span.

\section{Theory}

The theory behind our approach can be outlined as follows. Assume that individuals have preferences over a vector of private goods $\mathbf{x}=\left[x_{1}, \ldots, x_{K}\right]$ and a vector of environmental commodities (experiences), $\mathbf{e}=\left[e_{1}, \ldots, e_{P}\right]$, that can be translated into a utility function that is weakly separable in $\mathbf{x}$ and $\mathbf{e}$ :

$U(\mathbf{x}, \mathbf{e})=U\left(\mathbf{x}, u^{e}(\mathbf{e})\right)$ 
Following Freeman (2003), we assume that environmental commodities, e, are produced using environmental attributes, ${ }^{5} \mathbf{A}=\left(A_{1}, \ldots, A_{k}\right)$, and market goods, $\mathbf{z}=$ $\left(z_{1}, \ldots, z_{m}\right)$, according to:

$e_{r}=e(\mathbf{z}, \mathbf{A}) \quad r=1, \ldots, l$

The production function (2) has the properties that $e$ is increasing in $\mathbf{A}$ and $\mathbf{z}$, and that all inputs are essential in the production of $e$. In other words, both environmental attributes and market goods contribute to production of outdoor recreational experiences. By substituting (2) into (1), we obtain the following optimization problem:

$$
\max _{\mathbf{x}, \mathbf{z}}\left\{U\left(\mathbf{x}, u^{e}(\mathbf{e}(\mathbf{z}, \mathbf{A}))\right\} \quad \text { s.t. } \quad \mathbf{p}_{x} \mathbf{x}+\mathbf{p}_{z} \mathbf{z} \leq y,\right.
$$

where $\mathbf{p}_{x}$ and $\mathbf{p}_{z}$ are the price vectors corresponding to $\mathbf{x}$ and $\mathbf{z}$ respectively, and $y$ is the expenditure on private and complementary goods.

The first order conditions to this problem implicitly define the demand functions for the "instrumental" goods, $\mathbf{z}$, as a function of prices, income, attributes, preferences, and production technology, i.e.:

$z_{i}=z\left(\bar{p}_{x}, \mathbf{p}_{z}, \mathbf{A}, y\right) \quad i=1, \ldots, m$

where $\bar{p}_{x}$ is the price index for private goods, and $y$ is expenditure on goods that are complementary to environmental goods. ${ }^{6}$

According to equation (4), changes over time in expenditure on $z_{i}$ may result from changes in prices, income, or environmental attributes. However, we do not attempt to account here for changes in environmental attributes, and therefore consider them to be constant over time. Thus equation (4) constitutes the basis for our analysis, and will serve as a starting point in the specification of the econometric model in the following section.

5 Freeman gives examples of environmental attributes, such as number of fish per volume of water and water quality. Here, we may add air quality, sounds, wild-life, ski tracks and number of sunny days.

6 The reason for using $\bar{p}_{x}$ instead of a vector of private good prices is the assumption of weak separability between private and public goods. 


\section{The Modeling Framework}

In this section we formulate a demand system for public and private goods. In the first stage, the household determines, given its total budget, how much to spend on food, energy goods, transportation, and other goods as private groups, and outdoor recreation services as a public group. In the second stage, the household allocates resources within each of these groups. For example, given a specific amount of money to be spent on transportation, the household determines how much of that should be allocated to gasoline, car maintenance, and public transport. In the same manner, the household determines in the second stage how to use its budget for outdoor recreation. In this case, the household can choose between "equipment for sporting, fishing and camping”, and “other recreational goods”. Our main objective is to model and estimate household choices in the first and second stage.

The Linear Almost Ideal Demand system (LAIDS) is one of the most popular demand models for estimation of Engel curves. In the empirical estimation of Engel curves, nonlinearity has been found to be important for some goods. For instance, Banks et al. (1997) found that the Engel curves for some specific goods in the UK are non-linear in the logarithm of expenditure. To overcome the problem of non-linearity, Banks et al. (1997) developed the Quadratic Almost Ideal Demand system (QUAIDS).

In this paper we take the quadratic AIDS (QUAIDS) model as our basic specification. Given the structure of two-stage budgeting, we can express demand for the complementary goods, $z$, and pure private aggregates, $x$, in budget share form for household $h$ as: ${ }^{7}$

$$
\begin{aligned}
& w_{(z) t}^{h}=\alpha_{(z)}^{h}+\gamma_{(z z)}^{h} \ln \bar{p}_{(z) t}+\gamma_{(z x)}^{h} \ln \bar{p}_{(x) t}+\beta_{(z)}^{h}\left(\ln R_{t}^{h}-\ln \bar{P}_{t}\right)+\lambda_{(z)}^{h}\left(\ln R_{t}^{h}-\ln \bar{P}_{t}\right)^{2}+\varepsilon_{(z) t}^{h} \\
& w_{(x) t}^{h}=\alpha_{(x)}^{h}+\gamma_{(x z)}^{h} \ln \bar{p}_{(z) t}+\gamma_{(x x)}^{h} \ln \bar{p}_{(x) t}+\beta_{(x)}^{h}\left(\ln R_{t}^{h}-\ln \bar{P}_{t}\right)+\lambda_{(x)}^{h}\left(\ln R_{t}^{h}-\ln \bar{P}_{t}\right)^{2}+\varepsilon_{(x) t}^{h}
\end{aligned}
$$

Equation (5) describes the budget share for the public commodity group for household $h$ $=1, \ldots, H$, where $w_{(z) t}$ denotes the budget share for group $z$ in period $t, \bar{p}_{(z) t}$ and $\bar{p}_{(x) t}$ are group price indices for public and private goods, respectively $R_{t}$ is total expenditure

7 In the estimation, we have three main private groups (foodstuff, energy goods, and transportation). Thus $x$ in equation (6) can be viewed as a vector of private goods, and the group price index for private goods as a vector of group price indices. 
on public and private goods, $\bar{P}_{t}$ is the overall consumer price index, and $\varepsilon_{(z) t}$ is the error term. In the same manner, equation (6) gives the budget share for private commodities, where $w_{(x) t}$ denotes the budget share for private goods $x$ in period $t, \bar{p}_{(x) t}$ is a group price index for private goods and $\varepsilon_{(x) t}$ is the error term. The parameters to be estimated are $\alpha, \gamma, \beta$, and $\lambda$.

The demand functions for household $h$ in goods within the sub-groups have the same functional form as the demand equations for the main groups. The demand function for goods within the $z^{\text {th }}$, and the $x^{\text {th }}$, groups can thus be written as

$$
w_{(z) i t}^{h}=\alpha_{(z) i}^{h}+\sum_{j=1}^{m} \gamma_{(z) i j}^{h} \ln p_{(z) j t}+\beta_{(z) i}^{h}\left(\ln R_{(z) t}^{h}-\ln \bar{p}_{(z) t}\right)+\lambda_{(z) i}^{h}\left(\ln R_{(z) t}^{h}-\ln \bar{p}_{(z) t}\right)^{2}+\varepsilon_{(z) i t}^{h},
$$

where $i=1, \ldots, m$ denotes the number of goods within $z$ and $h=1, \ldots, H$ denotes households' and

$$
w_{(x) i t}^{h}=\alpha_{(x) i}^{h}+\sum_{j=1}^{n} \gamma_{(x) i j}^{h} \ln p_{(x) j t}+\beta_{(x) i}^{h}\left(\ln R_{(x) t}^{h}-\ln \bar{p}_{(x) t}\right)+\lambda_{(x) i}^{h}\left(\ln R_{(x) t}^{h}-\ln \bar{p}_{(x) t}\right)^{2}+\varepsilon_{(x) i t}^{h},
$$

where $i=1, \ldots, n$ denotes the number of goods within $x$.

Equations (7) and (8) give the allocation within the public and private groups, where $w_{(z) i t}$ and $w_{(x) i t}$ are the budget shares for the individual goods within each group, $p_{(z) j}$ and $p_{(x) j}$ are the commodity prices within respective group, $R_{(z) t}$ is the total expenditure on goods complementary to public goods, and $R_{(x) t}$ is the total expenditure on the pure private goods.

In any time period $t$, we assume that the prices of goods are equal across all households. This means that since we will estimate the model for each cross-section separately, the prices can be included directly into the intercept term for any time period. Thus, for each cross-section we can write the budget shares to be estimated as: ${ }^{8}$

8 This means that we can exclude the price in the estimation of each cross-section. 


$$
\begin{aligned}
& w^{h}(z) t=\alpha_{(z) t}^{h}+\beta_{(z) t}^{h}\left(\ln R_{t}^{h}\right)+\lambda_{(z) t}^{h}\left(\ln R_{t}^{h}\right)^{2}+\varepsilon_{(z) t}^{h} \\
& w^{h}(x) t=\alpha_{(x) t}^{h}+\beta_{(x) t}^{h}\left(\ln R_{t}^{h}\right)+\lambda_{(x) t}^{h}\left(\ln R_{t}^{h}\right)^{2}+\varepsilon_{(x) t}^{h} \\
& w^{h}(z) i t=\alpha_{(z) i t}^{h}+\beta_{(z) i t}^{h}\left(\ln R_{(z) t}^{h}\right)+\lambda_{(z) i t}^{h}\left(\ln R_{(z) t}^{h}\right)^{2}+\varepsilon_{(z) i t}^{h}, \quad i=1, \ldots, m \\
& w^{h}(x) i t=\alpha_{(x) i t}^{h}+\beta_{(x) i t}^{h}\left(\ln R_{(x) t}^{h}\right)+\lambda_{(x) i t}^{h}\left(\ln R_{(x) t}^{h}\right)^{2}+\varepsilon_{(x) i t}^{h}, \quad i=1, \ldots, n
\end{aligned}
$$

where $t=1, \ldots, T$ is the number of cross-sections, and where $\alpha_{(z) t}^{h}, \alpha_{(x) t}^{h}, \alpha_{(z) i t}^{h}$, and $\alpha_{(x) i t}^{h}$ now include the (constant) price.

According to this system, equations (9) and (10) describe how household $h$ allocate its total expenditure between public and private groups respectively, while equation (11) and (12) describe the allocation of household expenditure to goods within the public and private groups.

\section{Data and Econometric Consideration}

This study uses cross-sectional data from four Swedish Family Expenditure Surveys (FES) 1913, 1984, 1988, and 1996. The first household expenditure survey in Sweden was performed in 1913, covering approximately 900 households in eight towns. The 1984 survey included 4354 households, the 1988 survey 3764 households, and the 1996 survey 1104 households. The surveys contain expenditure data on a rather disaggregated level. Here, however, we will focus on four main aggregates: ${ }^{9}$

Outdoor recreation: Expenditure on "sporting, fishing, and camping equipment", and "other recreation goods".

Transport: Expenditure on "petrol", "car maintenance", and "public and other transport".

Energy goods: Expenditure on "electricity", and "other energy goods".

Foodstuffs: Expenditure on "food" and "beverages".

Table 1 presents the budget shares for the four main groups and their sub-groups. As shown, household expenditure for outdoor recreation, transportation, and energy goods

\footnotetext{
9 The 1913 survey uses only an aggregate general title for recreational goods, which includes outdoor
} and indoor recreation and gives no data within the groups except for foodstuffs. 
have been fairly stable over time, although there is a weak negative trend in the energy goods share. However, the share of foodstuffs has decreased significantly, while approximately $45 \%$ of household expenditure went to foodstuff in 1913, this share declined to less than 30\% in 1984, and to less than 20\% in 1996.

Table 1 also shows that there was no dramatic change in household expenditure for most of the goods within the main groups, except for spending on sporting, fishing and camping equipment, which decreased substantially. Approximately $60 \%$ of household expenditure on recreation went to equipment in 1984, but by 1996 this share had decreased to $35 \%$.

Household characteristics may affect consumer behavior with respect to these four groups of goods. There are basically two different ways to consider different household characteristics in the model estimation (Pollak and Wales, 1992). The first technique is to consider the sample as a whole and use different dummy variables to capture different household characteristics. The second is to divide the sample into homogenous sub-samples depending on household characteristics. In this paper, we follow the first approach. The variables relating to household characteristics were: (a) a continuous variable that represents the number of adults, and (b) three dummy variables for the cases when the household has one child, two children, or more than two children less than 18 years of age. ${ }^{10}$ We also create regional dummy variables (seven for the eight census regions in the 1913 survey, and five for the six census regions in the 1984, 1988, and 1996 surveys). In the estimation, we use total expenditure rather than income because expenditure better reflects permanent income.

10 We also estimated the model by using dummy variables for the number of adults, but this did not change the results. 
Table 1. Descriptive statistics of budget shares of various commodity goods.

\begin{tabular}{|c|c|c|c|c|c|c|c|c|}
\hline & \multicolumn{2}{|c|}{1913} & \multicolumn{2}{|c|}{1984} & \multicolumn{2}{|c|}{1988} & \multicolumn{2}{|c|}{1996} \\
\hline & $\begin{array}{c}\text { Budget } \\
\text { share } \\
\%\end{array}$ & s.e & $\begin{array}{c}\text { Budget } \\
\text { share } \\
\%\end{array}$ & s.e & $\begin{array}{c}\text { Budget } \\
\text { share } \\
\%\end{array}$ & s.e & $\begin{array}{c}\text { Budget } \\
\text { share } \\
\%\end{array}$ & s.e \\
\hline \multicolumn{9}{|c|}{ MAIN GROUPS } \\
\hline Foodstuff & 0.47 & $(0.07)$ & 0.30 & $(0.09)$ & 0.27 & $(0.09)$ & 0.18 & $(0.07)$ \\
\hline Energy goods & 0.05 & $(0.01)$ & 0.14 & $(0.11)$ & 0.14 & $(0.10)$ & 0.13 & $(0.12)$ \\
\hline Transport & 0.02 & $(0.01)$ & 0.08 & $(0.06)$ & 0.07 & $(0.06)$ & 0.08 & $(0.07)$ \\
\hline Outdoor recreation & 0.01 & $(0.009)$ & 0.005 & $(0.01)$ & 0.005 & $(0.02)$ & 0.008 & $(0.02)$ \\
\hline Sum & 0.55 & & 0.525 & & 0.485 & & 0.498 & \\
\hline \multicolumn{9}{|c|}{ FOODSTUFFS } \\
\hline Food & 0.97 & $(0.03)$ & 0.90 & $(0.09)$ & 0.89 & $(0.10)$ & 0.86 & $(0.10)$ \\
\hline Beverages & 0.03 & $(0.03)$ & 0.10 & $(0.09)$ & 0.11 & $(0.10)$ & 0.14 & $(0.10)$ \\
\hline Sum & 1.00 & & 1.00 & & 1.00 & & 1.00 & \\
\hline \multicolumn{9}{|c|}{ ENERGY GOODS } \\
\hline Electricity & & & 0.39 & $(0.40)$ & 0.37 & $(0.32)$ & 0.34 & $(0.21)$ \\
\hline Other energy goods & & & 0.61 & $(0.40)$ & 0.63 & $(0.31)$ & 0.66 & $(0.28)$ \\
\hline Sum & & & 1.00 & & 1.00 & & 1.00 & \\
\hline \multicolumn{9}{|c|}{ TRANSPORT } \\
\hline Petrol & & & 0.51 & $(0.33)$ & 0.51 & $(0.12)$ & 0.60 & $(0.33)$ \\
\hline Car maintenance & & & 0.40 & $(0.31)$ & 0.41 & $(0.33)$ & 0.28 & $(0.31)$ \\
\hline Public and other transport & & & 0.09 & $(0.12)$ & 0.08 & $(0.19)$ & 0.12 & $(0.21)$ \\
\hline & & & 1.00 & & 1.00 & & 1.00 & \\
\hline \multicolumn{9}{|c|}{ OUTDOOR RECREATION } \\
\hline $\begin{array}{l}\text { Equipment for sporting, } \\
\text { fishing, and camping }\end{array}$ & & & 0.61 & $(0.45)$ & 0.52 & $(0.42)$ & 0.37 & $(0.44)$ \\
\hline Other recreational goods & & & 0.39 & $(0.42)$ & 0.48 & $(0.44)$ & 0.63 & $(0.46)$ \\
\hline Sum & & & 1.00 & & 100 & & 1.00 & \\
\hline Number of observation & \multicolumn{2}{|c|}{908} & \multicolumn{2}{|c|}{4354} & \multicolumn{2}{|c|}{3764} & \multicolumn{2}{|c|}{1104} \\
\hline
\end{tabular}

Note: Standard errors within parentheses.

In this study, we estimate the quadratic almost ideal demand system in expenditure form. To capture the effect of household size and composition on the consumer preferences, we follow Blundell et al. (1993) in allowing the parameters in the model $\left(\alpha_{i t}^{h}, \beta_{i t}^{h}\right.$, and $\lambda_{i t}^{h}$ ) to vary over time and over different types of household characteristics (e.g. household size and composition, as well as place of residence):

$$
\begin{array}{ll}
\alpha_{(r) t}^{h}=\alpha_{(r) 0}+\sum_{k=1}^{q} \alpha_{(r) k} D_{h k t} & r=z, x \\
\beta_{(r) t}^{h}=\beta_{(r) 0}+\sum_{k=1}^{q} \beta_{(r) k} D_{h k t} & r=z, x
\end{array}
$$




$$
\begin{array}{lc}
\lambda_{(r) t}^{h}=\lambda_{(r) 0}+\sum_{k=1}^{q} \lambda_{(r) k} D_{h k t} & r=z, x \\
\alpha_{(z) i t}^{h}=\alpha_{(z) i 0}+\sum_{k=1}^{q} \alpha_{(z) i k} D_{h k t} & i=1 \ldots, m, h=1, \ldots, H \\
\alpha_{(x) i t}^{h}=\alpha_{(x) i 0}+\sum_{k=1}^{q} \alpha_{(x) i k} D_{h k t} & i=1 \ldots, n, h=1, \ldots, H \\
\beta_{(z) i t}^{h}=\beta_{(z) i 0}+\sum_{k=1}^{q} \beta_{(z) i k} D_{h k t} & i=1 \ldots, m, h=1, \ldots, H \\
\beta_{(x) i t}^{h}=\beta_{(x) i 0}+\sum_{k=1}^{q} \beta_{(x) i k} D_{h k t} & i=1 \ldots, n, h=1, \ldots, H \\
\lambda_{(z) i t}^{h}=\lambda_{(z) i 0}+\sum_{k=1}^{q} \lambda_{(z) i k} D_{h k t} & i=1 \ldots, m, h=1, \ldots, H \\
\lambda_{(x) i t}^{h}=\lambda_{(x) i 0}+\sum_{k=1}^{q} \lambda_{(x) i k} D_{h k t} & i=1 \ldots, n, h=1, \ldots, H
\end{array}
$$

$D_{h k t}$ represents dummy variables for demographic characteristics, including number of children and a dummy variable for different regions. The number of dummy variables, $q$, is equal to 11 in the 1913 survey, and 9 in the1984, 1986, and 1996 surveys.

Given the estimates of the parameters in the demand model, we can now calculate the income elasticities as ${ }^{11}$

$$
\xi_{i}^{h}=1+\frac{\hat{\beta}_{i t}^{h}}{\hat{w}_{i t}^{h}}+\frac{2 \hat{\lambda}_{i t}^{h} \ln R_{t}^{h}}{\hat{w}_{i t}^{h}}
$$

Where $\xi_{i}^{h}$ denotes household $h$ 's income elasticity for good $i$. A good with an income elasticity larger than one is a luxury, while a good with an income elasticity lower than one is a necessity. However, equation (16) implies that each good can be either a necessity or a luxury for different households, depending upon the distribution of total expenditure and the household specific parameters.

Finally, the most challenging problem is how to deal with observed zero expenditure, since the parameter estimation tends to be biased in a regression model where a large

11 The income elasticity for a specific good denotes the percentage change in the consumption of the good as a result of the percentage change in total consumption. See Chalfant (1987) for a derivation of income elasticitiy in an AIDS model. 
proportion of the dependent variable is zero (Deaton 1986, Greene 2000). ${ }^{12}$ There are at least two possible reasons for an observation of zero. One is that the household is not interested in the good. Another is that even if a household does have a preference for a good, expenditures may be infrequent and lie outside the observation period. To be sure that our data is consistent with the estimation results, we estimate the demand equation by an alternative estimator (Tobit estimator) which assumes that any observation for which the dependent variable takes a zero value is truncated. ${ }^{13}$ However, this does not change the results concerning income elasticity to any great extent. ${ }^{14}$

\section{Results}

This section presents the results of applying the parametric approach to estimate the income elasticity for outdoor recreation, energy goods, transportation, and foodstuffs for Swedish households in four different years during the twentieth century. We start the analysis by testing the functional form for the expenditure equations in order to decide whether the non-linear expenditure term should be included in the model or not. Table 2 shows the results of this test.

According to the F-tests in table 2, we cannot reject linearity for any of the main groups in any of the surveys except for the energy goods group in 1984 and 1988. Among the sub-groups, linearity cannot be rejected for any of the goods within the foodstuffs group in all surveys, for public and other transport in the 1984, 1988, and 1996 surveys, or for any goods within the recreation group in the 1996 survey.

12 The proportion of zero expenditure on outdoor recreation in our surveys is approximately 35\%.

13 The standard Tobit model was originally formulated by Tobin (1958).

14 The results from the Tobit estimator was compared with OLS estimator which we used in this estimation. 
Table 2. Test for Linearity (F-test).

\begin{tabular}{|c|c|c|c|c|}
\hline & 1913 & 1984 & 1988 & 1996 \\
\hline \multicolumn{5}{|c|}{ MAIN GROUPS } \\
\hline Foodstuff & 0.64 & 1.01 & 0.91 & 0.50 \\
\hline Energy goods & 0.86 & $2.45^{*}$ & $5.82 *$ & 0.89 \\
\hline Transport & 0.24 & 0.73 & 1.79 & 0.29 \\
\hline Outdoor recreation & 0.41 & 0.21 & 0.12 & 0.15 \\
\hline \multicolumn{5}{|c|}{ FOODSTUFFS } \\
\hline Food & 1.85 & 0.70 & 0.51 & 1.43 \\
\hline Beverages & 1.85 & 0.69 & 0.51 & 1.43 \\
\hline \multicolumn{5}{|c|}{ ENERGY GOODS } \\
\hline Electricity & & $8.19 *$ & $12.55^{*}$ & 1.93 \\
\hline Other energy goods & & $8.19 *$ & $12.56^{*}$ & 1.93 \\
\hline \multicolumn{5}{|c|}{ TRANSPORT } \\
\hline Petrol & & $31.54 *$ & $22.36 *$ & $13.60 *$ \\
\hline Car maintenance & & $31.89 *$ & $23.22 *$ & $11.80 *$ \\
\hline Public and other transport & & 0.46 & 0.74 & 1.86 \\
\hline \multicolumn{5}{|c|}{ OUTDOOR RECREATION } \\
\hline $\begin{array}{l}\text { Equipment for sporting, } \\
\text { fishing, and camping }\end{array}$ & & $3.68^{*}$ & $2.43^{*}$ & 1.71 \\
\hline Other recreational goods & & $3.68 *$ & $2.43 *$ & 1.72 \\
\hline
\end{tabular}

* Linearity rejected at the $5 \%$ level.

Following the specifications in equations (9), (10), (11), and (12), the demand equations for the goods in the main groups and within the main groups are estimated by ordinary least squares (OLS) and the functional form is determined according to the linearity tests above. ${ }^{15}$ For example, in the main group, the linear form should be used in the estimation of every group except energy goods for the 1913 and 1988 surveys.

Table 3 presents estimates with standard errors of the income elasticities of the various goods. These elasticities are computed from the coefficient estimates, the estimated budget shares, and the mean total expenditures for all households in every survey, following equation (22). Standard errors are computed with the delta method (see Greene, 2000).

15 Estimates with standard errors of the parameters of the demand equations are available from the author upon request. 
Table 3. Estimated income elasticities, standard errors within parentheses.

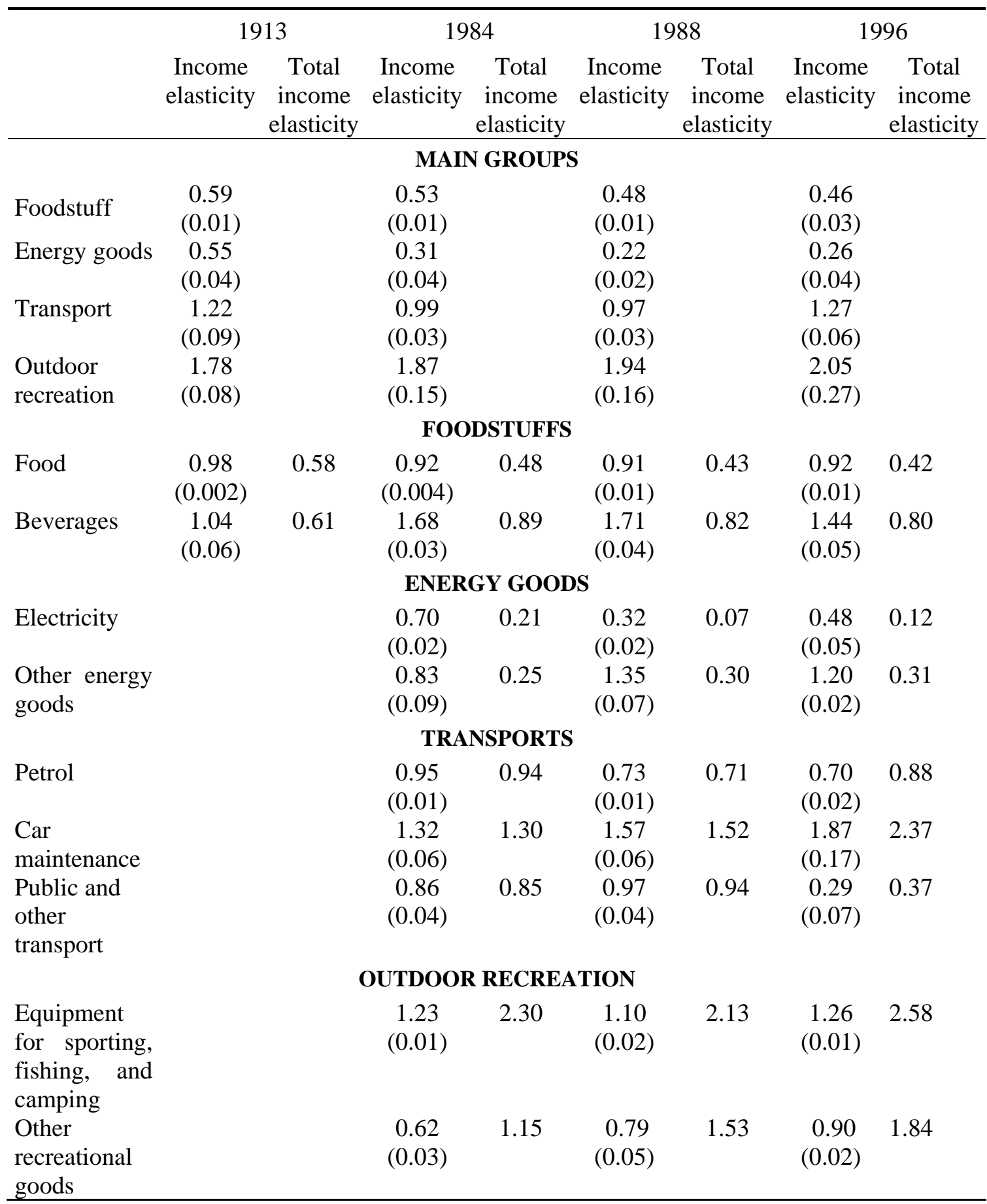

Note: total income elasticity for any good within the main group of goods is calculated by multiplying the income elasticity for the main group by the income elasticity within the main group.

Elasticities can be examined in two different ways, focusing either on the differences between different goods, or on differences over time.

Considering differences over time, we can conclude that outdoor recreation seems to be a luxury good in 1913, and has retained that classification until 1996. This result is 
consistent with previous research such as that of Costa (1997), Pereyra and Rossi (1998), Miles et al. (2002), and Larsen (2001). However, it contradicts to some extent the finding of Kriström and Riera (1996), who showed some empirical evidence that environmental amenities are not luxury.

Our results support the classification of environmental goods as luxury goods, as income elasticities are estimated above one for all the time periods. This, in combination with the fact that income in Sweden has increased over the last 100 years, implies that demand for environmental goods has been non-decreasing for that time period. Thus, if we have an increase in future income, we may expect a more than proportional increase in demand for recreation goods. This is consistent with the assumed shape of the environmental Kuznets curve (EKC).

Table 3 also shows that the income elasticity for the main groups seems to remain constant over time. The income elasticity fluctuates around two for outdoor recreation and around one for transportation. On the other hand, the income elasticities for food and energy goods decreased slightly between 1913 and 1996. ${ }^{16}$ This implies that we cannot reject the hypothesis that the budget for these goods is stable over time, indicating that consumer preferences for expenditures on these specific commodities have not changed significantly over time. ${ }^{17}$

Concerning the differences between different goods, the results in Table 3 show that the income elasticities for transportation fluctuate around one over the various crosssections. For energy goods and foodstuffs, the elasticity is smaller than one, indicating that these goods are considered as necessities.

From Table 3, we also notice that the total income elasticities within the main groups indicate that equipment for sporting, swimming, and camping, car maintenance and other recreational goods are luxuries, (i.e. they have income elasticities higher than one), while food, petrol, public and other transport, electricity, and other energy goods are necessities, since they have income elasticities that are less than one. Two tailed ttests show that the income elasticities for all goods are significantly different from one

\footnotetext{
16 Remember that the expenditure elasticities are estimated for independent cross-sections, where households face the same prices. Between cross-sections, there will be price changes and quality changes, however this is not considered here.

17 Since the difference in the income elasticities for these goods is quite small, we cannot reject stability.
} 
except for the transport group in the 1984 and 1988 surveys and beverages in the 1913 survey (the results from this test are presented in Table A1 in Appendix A).

Income elasticities evaluated at the mean for different categories of household are presented in Tables A2-A5 in Appendix A. From these results, we see that there are no large differences in income elasticities between households in different regions or of different family size, indicating that household location and family size do not have a big impact on consumer preferences for expenditure on these specific commodities.

In summary, we find that outdoor recreation is a luxury good and that its luxury status seems to be robust over time. Foodstuffs and energy goods, however, serve as necessities. We may also conclude that the demand for transportation has increased more than the demand for foodstuffs and energy goods, but less than the demand for outdoor recreation.

\section{Concluding Remarks}

In this paper, we estimated the income elasticity of demand for recreational services and other traditional groups of goods in Sweden, and tested for potential changes in such estimates over the twentieth century. The data were drawn from Swedish household surveys for the years 1913, 1984, 1988, and 1996. Because of the difficulty of directly observing the demand for recreational services, we employed an indirect methodology by using the demand for some outdoor goods as a proxy for the recreational services demand. In line with most prior research, our results confirm the expectation that recreational services, as a public good, is a luxury good in Sweden.

In relation to the shape of an environmental Kuznets curve (EKC), our results support the suggested shape of the EKC, at least to some extent. We found that outdoor recreational service is a luxury good and that demand was non-decreasing during the whole period. Our contribution supplements that of other studies of the phenomenon (Grossman and Krueger, 1995, Hilton and Levinson, 1998, Selden and Song, 1995).

The results also show that recreational services have maintained this luxury good attribute in Sweden over the twentieth century, indicating no significant change in consumer preferences over time. The income elasticity for transportation goods fluctuated around one during the period of interest, while both energy goods and food 
maintained their attributes as necessities during this period, with a steady decline in their income elasticities over time.

According to our results, expenditure on environmental services increases with income. This is true when all other factors remain constant. However, when changes occur in preferences, prices, environmental attributes, and the production structure for outdoor recreational experiences, it becomes difficult to predict the demand for environmental services in the future. This is a question of interest for future research. Quality changes are well-known causes of data misinterpretations, e.g., the difficulties in disentangling the relation between changes in quality and price. Further, the demand function is also a function of relative prices. If outdoor recreation becomes cheaper to produce, then, all other things being equal, we would expect more households to consume it. If prices, preferences, and mean income change at the same time, interpretation becomes difficult. As it is, this study relegates price effects to a constant term. 


\section{References}

Banks, J., Blundell, R. and Lewbel, A. (1997) Quadratic Engel curves and consumer demand. The Review of Economics and Statistics, 79.

Batemen, I.J. and Willis, K.G. (1999) Valuing Environmental Preferences:Theory and Practice of the Contingent Valuation Method in the US, EU and Developing Countries. Oxford University Press, Oxford, UK.

Blundell, R., Pashardes, P. and Weber, G. (1993), What Do we Learn About Consumer Demand Patterns from Micro Data? The American Economic Review, 83.

Chalfant, J.A. (1987) A Globally Flexible, Almost Ideal Demand System. Journal of Business and Economic Statistics 5.

Chichilinisky, G. (1998) The Knowledge Revolution. Journal of International Trade and Economic Development, 7.

Costa, D. (1997) Less of a luxury: The Rise of Recreation since 1888. National Bureau of Economics Research, Working Paper, 6054.

Deaton, A. (1986) “Demand Analysis”, in Handbook of Econometrics, eds. Z. Griliches and M.D. Intriligator (North-Holland, Amsterdam).

Deaton, A. and Muellbauer, J. (1980) An Almost Ideal Demand System. The American Economic Review, 70.

Flores, N. and Carson, R. (1997) The Relationship between the Income Elasticities of Demand and Willingness to Pay. Journal of environmental Economics and management, 33.

Freeman, A.M. (2003) The Measurement of Environmental and Resources Value. Theory and Method, Washington, DC: Resources for the Future.

Greene, W.H. (2000) Econometric Analysis, Fourth Edition, Prentice Hall, Englewood Cliffs, NJ.

Groot, H.L.F. (1999) Structural Change, Economic Growth and the Environmental Kuznets Curve. A Theoretical Perspective. OCFEB Research Memorandum 9911, Working Paper Series 1, Vrije Universiteit, Amsterdam.

Grossman, G.M. and Krueger, A.B. (1995) Economic Growth and the Environment. The Quarterly Journal of Economics, 110.

Hilton, F.G. and Levinson, A. (1998) Factoring the Environmental Kuzents Curve: Evidence from Automotive Lead Emissions. Journal of Environmental Economics and Management, 35. 
Hökby, S. and Söderqvist, T. (2001) Elasticities of Demand and Willingness to pay for Environmental services in Sweden. Beijer Discussion paper series No. 137, Beijer International Institute of Ecological Economics, The Royal Swedish academy of sciences, Stockholm.

Kanninen, B.J. and Kriström, B. (1992) Welfare Benefit Estimation and Income Distribution. Beijer Discussion paper series No. 20, Beijer International Institute of Ecological Economics, The Royal Swedish academy of sciences, Stockholm.

Kriström, B. and Riera, P. (1996) Is the Income Elasticities of Environmental Improvements Less than One?. Environmental and Resources Economics, 7.

Larsen, R.E. (2001) Revealing Demand for Nature experiences Using Purchase Data on Equipment and Lodging. Discussion paper No.305, Statistic Norway, Research Department.

Lopez, R. (1994) The Environment as a Factor of Production. The Effects of Economic Growth and Trade Liberalization. Journal of Environmental Economics and Management, 27.

Mäler, K.G. (1974) Environmental economics: A Theoretical Inquiry. Baltimore: Johns Hopkins University Press.

McConnell, K. (1997) Income and the Demand for Environmental Quality. Environment and Development Economics, 2.

Miles, D., Pereyra, A. and Rossi, M. (2002) The Consistent estimation of Income Elasticity of Environmental Amenities in Uruguay. Studios Economics, 17.

Mitchell, R.C. and Carson, R.T. (1989) Using Survey to value Public Goods: The Contingent Valuation Method. Resources for the Future, Washington, D.C.

Pereyra, A. and Rossi, M. (1998) Are Environmental Goods a Luxury?, Working paper 13, University of Uruguay.

Pollak, R. and Wales, T. (1992) Demand System Specification and Estimation. Oxford University press, Oxford, UK.

Segal, J.M. (2001) What We Work for Now, New York Times, September 3.

Selden, T. and Song, G. (1995) Neoclassical Growth, the J Curve for Abatement, and the Inverted U for Pollution. Journal of Environmental Economics and Management, 29.

Stern, D.I. and Common, M.S. (2001) Is there an environmental Kuznets curve for sulfur?, Journal of Environmental Economics and Management, 41. 
Tobin, J. (1958) Estimation of Relationships for Limited Dependent Variables, Econometrica, 26. 


\section{Appendix A}

Table A1: Test for an income elasticity different from 1 (t-test).

\begin{tabular}{|c|c|c|c|c|}
\hline & 1913 & 1984 & 1988 & 1996 \\
\hline \multicolumn{5}{|c|}{ MAIN GROUPS } \\
\hline Foodstuff & $-41.00 *$ & $-47.00 *$ & $-52.00 *$ & $-14.66 *$ \\
\hline Energy goods & $-11.25^{*}$ & $-17.25^{*}$ & $39.00 *$ & $-16.75 *$ \\
\hline Transport & $2.44^{*}$ & -0.33 & -1.00 & $4.50 *$ \\
\hline Outdoor recreation & $9.75^{*}$ & $5.80 *$ & $5.87 *$ & $3.88^{*}$ \\
\hline \multicolumn{5}{|c|}{ FOODSTUFFS } \\
\hline Food & $-10.00 *$ & $-20.00 *$ & $-9.00 *$ & $-8.00 *$ \\
\hline Beverages & 0.66 & $22.66^{*}$ & $17.75^{*}$ & $8.80 *$ \\
\hline \multicolumn{5}{|c|}{ ENERGY GOODS } \\
\hline Electricity & & $-15.00 *$ & $-42.50 *$ & $-10.40 *$ \\
\hline Other energy goods & & $-1.88 *$ & 5.00 & $10.00 *$ \\
\hline \multicolumn{5}{|c|}{ TRANSPORT } \\
\hline Petrol & & $-5.00 *$ & $-27.00 *$ & $-15.00 *$ \\
\hline Car maintenance & & $5.33^{*}$ & $9.50 *$ & $5.12^{*}$ \\
\hline Public and other transp. & & $-3.50 *$ & $-0.75^{*}$ & $-10.14 *$ \\
\hline \multicolumn{5}{|c|}{ OUTDOOR RECREATION } \\
\hline $\begin{array}{l}\text { Equipment for sporting, } \\
\text { fishing, and camping }\end{array}$ & & $23.00 *$ & $5.00 *$ & $26.00^{*}$ \\
\hline Other recreation goods & & $-12.66^{*}$ & $-4.20 *$ & $-5.00 *$ \\
\hline
\end{tabular}


Table A2: Estimated income elasticities in 1913.

\begin{tabular}{lllllllll}
\hline & $\begin{array}{l}\text { Food- } \\
\text { stuffs }\end{array}$ & $\begin{array}{l}\text { Standard } \\
\text { Error }\end{array}$ & $\begin{array}{l}\text { Energy } \\
\text { Goods }\end{array}$ & $\begin{array}{l}\text { Standard } \\
\text { Error }\end{array}$ & Transport & $\begin{array}{l}\text { Standard } \\
\text { Error }\end{array}$ & $\begin{array}{l}\text { Outdoor } \\
\text { Recreation }\end{array}$ & $\begin{array}{l}\text { Standard } \\
\text { Error }\end{array}$ \\
\hline C1 & 0.64 & $(0.01)$ & 0.55 & $\begin{array}{c}\text { Number of children } \\
(0.03)\end{array}$ & 1.12 & $(0.08)$ & 1.69 & $(0.09)$ \\
C2 & 0.66 & $(0.01)$ & 0.55 & $(0.03)$ & 1.07 & $(0.08)$ & 1.65 & $(0.09)$ \\
C3 & 0.61 & $(0.01)$ & 0.55 & $(0.03)$ & 1.17 & $(0.08)$ & 1.83 & $(0.09)$ \\
& & \multicolumn{7}{c}{ Region } \\
R1 & 0.66 & $(0.01)$ & 0.55 & $(0.03)$ & 1.07 & $(0.08)$ & 1.64 & $(0.09)$ \\
R2 & 0.67 & $(0.01)$ & 0.54 & $(0.03)$ & 1.06 & $(0.08)$ & 1.64 & $(0.09)$ \\
R3 & 0.66 & $(0.01)$ & 0.56 & $(0.03)$ & 1.06 & $(0.08)$ & 1.57 & $(0.09)$ \\
R4 & 0.66 & $(0.01)$ & 0.56 & $(0.03)$ & 1.07 & $(0.08)$ & 1.62 & $(0.08)$ \\
R5 & 0.66 & $(0.01)$ & 0.56 & $(0.03)$ & 1.07 & $(0.08)$ & 1.64 & $(0.09)$ \\
R6 & 0.67 & $(0.01)$ & 0.56 & $(0.03)$ & 1.04 & $(0.08)$ & 1.63 & $(0.09)$ \\
R7 & 0.67 & $(0.01)$ & 0.55 & $(0.03)$ & 1.06 & $(0.12)$ & 1.66 & $(0.09)$ \\
\hline
\end{tabular}

Notes: C1 1 child below 18, C2= 2 children below 18, C3= more than 2 children below 18,

R1=Uppsala, R2= Eskilstuna, R3= Jönköping, R4=Malmö, R5= Hälsingborg, R6= Gothenburg, R7=Västerås. Standard errors within parentheses.

Table A3 : Estimated income elasticities in 1984.

\begin{tabular}{lllllllll}
\hline & $\begin{array}{l}\text { Food- } \\
\text { stuffs }\end{array}$ & $\begin{array}{l}\text { Standard } \\
\text { Error }\end{array}$ & $\begin{array}{l}\text { Energy } \\
\text { Goods }\end{array}$ & $\begin{array}{l}\text { Standard } \\
\text { Error }\end{array}$ & Transport & $\begin{array}{l}\text { Standard } \\
\text { Error }\end{array}$ & $\begin{array}{l}\text { Outdoor } \\
\text { Recreation }\end{array}$ & $\begin{array}{l}\text { Standard } \\
\text { Error }\end{array}$ \\
\hline C1 & 0.64 & $(0.01)$ & 0.32 & $\begin{array}{c}\text { Number of children } \\
(0.03)\end{array}$ & 0.92 & $(0.03)$ & 1.89 & $(0.13)$ \\
C2 & 0.61 & $(0.01)$ & 0.35 & $(0.03)$ & 0.93 & $(0.03)$ & 1.85 & $(0.14)$ \\
C3 & 0.61 & $(0.01)$ & 0.33 & $(0.03)$ & 0.94 & $(0.03)$ & 1.87 & $(0.13)$ \\
& & \multicolumn{7}{c}{ Region } \\
R1 & 0.65 & $(0.01)$ & 0.35 & $(0.03)$ & 0.92 & $(0.03)$ & 1.89 & $(0.13)$ \\
R2 & 0.65 & $(0.01)$ & 0.35 & $(0.03)$ & 0.92 & $(0.03)$ & 1.88 & $(0.13)$ \\
R3 & 0.65 & $(0.01)$ & 0.36 & $(0.03)$ & 0.92 & $(0.03)$ & 1.90 & $(0.13)$ \\
R4 & 0.65 & $(0.01)$ & 0.34 & $(0.03)$ & 0.92 & $(0.03)$ & 1.89 & $(0.13)$ \\
R5 & 0.65 & $(0.01)$ & 0.36 & $(0.03)$ & 0.93 & $(0.03)$ & 1.90 & $(0.13)$ \\
R6 & 0.65 & $(0.01)$ & 0.35 & $(0.03)$ & 0.93 & $(0.03)$ & 1.90 & $(0.13)$ \\
\hline
\end{tabular}

Notes: C1= 1 child below 18, C2= 2 children below 18, C3= more than 2 children below 18, R1 = Stockholm, R2= Gothenburg/Malmö, R3= major towns, R4=southern areas, R5= major towns northern areas, R6= northern areas. Standard errors within parentheses. 
Table A4 : Estimated income elasticities in 1988.

\begin{tabular}{lllllllll}
\hline & $\begin{array}{l}\text { Food- } \\
\text { stuffs }\end{array}$ & $\begin{array}{l}\text { Standard } \\
\text { Error }\end{array}$ & $\begin{array}{l}\text { Energy } \\
\text { Goods }\end{array}$ & $\begin{array}{l}\text { Standard } \\
\text { Error }\end{array}$ & Transport & $\begin{array}{l}\text { Standard } \\
\text { Error }\end{array}$ & $\begin{array}{l}\text { Outdoor } \\
\text { Recreation }\end{array}$ & $\begin{array}{l}\text { Standard } \\
\text { Error }\end{array}$ \\
\hline C1 & 0.62 & $(0.01)$ & 0.16 & $\begin{array}{c}\text { Number of children } \\
(0.03)\end{array}$ & 0.91 & $(0.03)$ & 1.86 & $(0.13)$ \\
C2 & 0.61 & $(0.01)$ & 0.13 & $(0.03)$ & 0.90 & $(0.03)$ & 1.86 & $(0.14)$ \\
C3 & 0.58 & $(0.01)$ & 0.16 & $(0.03)$ & 0.91 & $(0.03)$ & 1.85 & $(0.14)$ \\
& & \multicolumn{7}{c}{ Region } \\
R1 & 0.60 & $(0.01)$ & 0.19 & $(0.03)$ & 0.89 & $(0.03)$ & 1.83 & $(0.13)$ \\
R2 & 0.59 & $(0.01)$ & 0.19 & $(0.03)$ & 0.89 & $(0.03)$ & 1.83 & $(0.13)$ \\
R3 & 0.61 & $(0.01)$ & 0.18 & $(0.03)$ & 0.89 & $(0.03)$ & 1.83 & $(0.13)$ \\
R4 & 0.59 & $(0.01)$ & 0.18 & $(0.03)$ & 0.89 & $(0.02)$ & 1.83 & $(0.13)$ \\
R5 & 0.61 & $(0.01)$ & 0.19 & $(0.03)$ & 0.90 & $(0.03)$ & 1.84 & $(0.13)$ \\
R6 & 0.60 & $(0.01)$ & 0.18 & $(0.03)$ & 0.90 & $(0.03)$ & 1.83 & $(0.13)$ \\
\hline
\end{tabular}

Notes: $\mathrm{C} 1=1$ child below $18, \mathrm{C} 2=2$ children below $18, \mathrm{C} 3=$ more than 2 children below 18 , R1 = Stockholm, R2= Gothenburg/Malmö, R3= major towns, R4=southern areas, R5= major towns northern areas, R6= northern areas. Standard errors within parentheses.

Table A5 : Estimated income elasticities in 1996.

\begin{tabular}{lllllllll}
\hline & $\begin{array}{l}\text { Food- } \\
\text { stuffs }\end{array}$ & $\begin{array}{l}\text { Standard } \\
\text { Error }\end{array}$ & $\begin{array}{l}\text { Energy } \\
\text { Goods }\end{array}$ & $\begin{array}{l}\text { Standard } \\
\text { Error }\end{array}$ & Transport & $\begin{array}{l}\text { Standard } \\
\text { Error }\end{array}$ & $\begin{array}{l}\text { Outdoor } \\
\text { Recreation }\end{array}$ & $\begin{array}{l}\text { Standard } \\
\text { Error }\end{array}$ \\
\hline C1 & 0.74 & $(0.03)$ & 0.32 & $\begin{array}{c}\text { Number of children } \\
(0.03)\end{array}$ & 1.11 & $(0.06)$ & 1.93 & $(0.24)$ \\
C2 & 0.72 & $(0.03)$ & 0.32 & $(0.04)$ & 1.13 & $(0.06)$ & 1.98 & $(0.25)$ \\
C3 & 0.67 & $(0.03)$ & 0.33 & $(0.04)$ & 1.13 & $(0.06)$ & 1.97 & $(0.26)$ \\
& & \multicolumn{7}{c}{ Region } \\
R1 & 0.70 & $(0.03)$ & 0.33 & $(0.04)$ & 1.10 & $(0.06)$ & 1.93 & $(0.24)$ \\
R2 & 0.67 & $(0.02)$ & 0.33 & $(0.04)$ & 1.11 & $(0.06)$ & 1.94 & $(0.24)$ \\
R3 & 0.67 & $(0.04)$ & 0.32 & $(0.03)$ & 1.11 & $(0.06)$ & 1.94 & $(0.24)$ \\
R4 & 0.70 & $(0.04)$ & 0.32 & $(0.03)$ & 1.11 & $(0.06)$ & 1.92 & $(024)$ \\
R5 & 0.72 & $(0.03)$ & 0.32 & $(0.03)$ & 1.10 & $(0.06)$ & 1.93 & $(0.24)$ \\
R6 & 0.71 & $(0.03)$ & 0.32 & $(0.03)$ & 1.11 & $(0.06)$ & 1.95 & $(0.24)$ \\
\hline
\end{tabular}

Notes: $\mathrm{C} 1=1$ child below $18, \mathrm{C} 2=2$ children below $18, \mathrm{C} 3=$ more than 2 children below 18 ,

$\mathrm{R} 1$ = Stockholm, R2= Gothenburg/Malmö, R3= major towns, R4=southern areas, R5= major towns northern areas, R6 = northern areas. Standard errors within parentheses 